\title{
THE RELEVANCE OF COMMUNITY INVOLVEMENT IN MILITARY COUNTER- INSURGENCY OPERATIONS IN NORTH EASTERN NIGERIA
}

\author{
Mustapha Salihu \\ Peace Conflict \& Strategic Studies, Nile University of Nigeria \\ elmustee1@gmail.com
}

Cite this article:

Mustapha Salihu (2021), The Relevance of Community Involvement in Military

Counter-Insurgency Operations in North Eastern Nigeria. African Journal of Social Sciences and Humanities Research 4(3), 14-32. DOI:

10.52589/AJSSHREX7CBPBI.

\section{Manuscript History}

Received: 8 May 2021

Accepted: 25 May 2021

Published: 2 June 2021

Copyright $\odot 2020$ The Author(s). This is an Open Access article distributed under the terms of Creative Commons Attribution-NonCommercialNoDerivatives 4.0 International (CC BY-NC-ND 4.0), which permits anyone to share, use, reproduce and redistribute in any medium, provided the original author and source are credited.
ABSTRACT: The paper highlights the increasing inpracticability of post-conflict peace-building in the context of emerging unconventional intra-state wars. It however ascertains the viability of a community-referent peace-building intervention as part of wider efforts to counter the influence of Boko Haram, while tending to humanitarian needs of affected communities. To do so, it employs textual analysis of qualitative secondary data, and builds on the submission of civil-military-relations theory as its framework for analysis. The result of the textual analysis of prior literature suggests counter insurgency operations in the northeast remain highly militarized, with inconsequential attention being paid to the humanitarian needs of affected communities. Despite its relevance, the use of military force has proven to be counterproductive given its state-referent orientation. Further to which sustained use of force has heightens the effect of the conflict on millions of civilians who have fled their communities in fear of Boko Haram and military highhandedness. To address the deficiencies of the pre-existing framework for countering insurgency, the paper proposes the implementation of a community centric, bottom-up approach which emphasizes the security, reconstruction and reintegration needs of civilians and defecting combatants. By prioritizing the inclusive needs of affected communities, the state is likely to win over the population, drawing on the combined expertise and resources of military and civilian actors. The implementation of such an approach will require in amongst others a reorientation of the military roles, a renewed relation of mutual assistance between civilian and military actors in the northeast.

KEYWORD: Community-Centric, Peace-building, Counter Insurgency, Boko Haram, Military and Civilian Actors 


\section{INTRODUCTION}

Seemingly, the implementation of peace-building interventions at the terminal stage of conflict, otherwise known as post-conflict peace-building, is becoming increasingly impracticable. Not only does violence break out after peace accords have been reached between conflicting parties, the rise of unconventional intra-state wars and resurgence of new actors like insurgents and terrorism reduces the viability of the approach. For instance, in Nigeria where protracted insurgencies, armed resource agitations and recurring ethno-religious conflicts constitute the fabrics of daily life, putting on hold peace-building till later stages of conflict seems counterproductive (US Army, 2018; Ferreira, 2017 and UNDP, 2017). With a particular focus on the Boko Haram insurgency, the study queries Nigeria's evident preference for a militarized counterinsurgency, despite its evident limitations (Salihu et al., 2021: Onapajo et al., 2020: Agbiboa, 2013). For one on-going military counter operation against Boko Haram takes place in a different environment from that of inter-state wars. Also, these operations take place in and around civilian populations, against arm-carrying non-state actors. Furthermore, the insurgent's resentment for constituted secular authority, their inclination to eliminate any opposition, and their seeming lack of to negotiate a ceasefire agreement reduces the probability of any meaningful peace agreement. It is imperative to note that this trend is not exclusively akin to Nigeria, elsewhere, post-conflict peace-building and reconstruction interventions have also been daunting. In the Democratic Republic of Congo (DRC), and the Central African Republic (CAR) for instance, despite the signing of peace accords, sustainable peace remains elusive. Not only have pacts been breached, but the states mentioned above have also fallen short of enjoying sustainable peace (Ferreira, 2017). Invariably, the spread of extremist religious ideology globally constitutes emerging dimensions to pre-existing challenges of peace-building (King et al., 2012). As such, the paper dismisses any prospects for attaining a viable post-conflict peace-building in the context of the Boko Haram insurgency; this, however, does not mean peace-building interventions cannot be deployed at different stages of the insurgency.

Against this backdrop, the paper shares the Committee for Conflict Transformation Support (2006) views, which presupposes that military interventions in the post-cold war era should be implemented as a constituent of a more comprehensive framework to prevent conflicts from escalating, recurring or spiralling humanitarian emergencies. Beyond the conventional state security referent orientation, it is imperative to review the rhetoric of the military to accommodate peace-building efforts targeted at averting the reoccurrence of the conditions that informed the conflict in the first instance. While acknowledging the significance of military warfare in incapacitating rising threats of Boko Haram insurgency as espoused by (Kalyvas, 2006; 2010), the counterproductive outcome of these operations in Afghanistan and Iraq (US Department of the Army, 2007) call for a review of Nigeria's strategy. A retired General of the US Army, David Petraeus, deployed to counter terrorism in Afghanistan, suggests the war on terror will be futile without the requisite firepower to outgun the insurgents. However, we cannot capture or kill our way to victory (Paul, 2012 and US Department of the Army, 2007).

\section{Research Objectives}

The paper seeks to ascertain the need or lack thereof to review and broaden the scope of Nigeria's framework for countering Boko Haram beyond the conventional kill or capture approach, to a more people's oriented interventions. Specifically, it looks at the possibility of implementing 'community-referent' counter-insurgency operations targeted at consolidating 
on relative military gains, through the implementation population winning strategy. In amongst others, these strategies include but not limited to; improved security, infrastructural reconstruction, rehabilitation, resettlement of displaced communities whilst military operations are sustained.

For this analysis, a community referent approach obtains from the logic of minimizing the negative effect of the insurgency on civilian populations. The structural design and practicability of such a model will require a social reorientation of the pre-existing relations between civilian (state, humanitarian agencies and development partners) and military (security forces, civilian task force) actors involved in counter-insurgency operations and humanitarian interventions.

\section{METHODOLOGY}

To do so, the paper employs the qualitative textual analysis of secondary data. The textual analysis which obtains in the review of pre-existing datasets is suitable for addressing research questions or propositions other than those examined in the original research. The logic of using prior data has become increasingly acceptable due to its widespread usage and recognition by researchers. Albeit its limitations as it concerns generalisation of findings and ethical issues in research, preliminary data in the form of qualitative data offer narratives that examine issues similar to those in prior studies but have not been examined or analyzed in a detailed fashion (Long-Sutehall et al., 2010). Material for analysis is sourced from journal articles, reports from the national and international organization, national dailies, expert opinions and policy papers from the United State Marine Field Manual for Counterinsurgency and those from the Office of the National Security Adviser as it concerns counter-insurgency.

For clarity, insurgency is herewith operationalized to mean an unconventional, protracted politico-military struggle undertaken to undermine the legitimacy of constituted authority with a view to building insurgents' strengths and control (Paul et al., 2017). On the reverse side of insurgency is counter-insurgency, a combination of coordinated military offensive, defensive and stability operations deployed to counter the capabilities of insurgencies to subvert constituted authority. It is argued to entail a set of civilian and military efforts to defeat insurgencies and address underlying causes and grievances (US Joint Chief of Staff, 2009).

\section{Research Structure}

In what follows, the paper examines the concept of peace-building from a Community Centric Approach (CCA). Simultaneously, the subsequent section problematizes Nigeria's reliance on the 'capture or kill approach' as the mainstay of its counter-insurgency operations, which is followed by a review of the Civil-Military Relations (CMR) Theory as a framework for analysis. In the subsequent section, the role of the military component of Nigeria's counterinsurgency framework is examined vis-à-vis its implications for peace-building. Further to this, prospects and challenges of redefining the role of the military in peace-building interventions. The last sections conclude the paper and offer recommendations in line with global best practices. 


\section{Peace-building, a Community Centric Approach}

After years of enlivening debates, former United Nations Secretary-General (UNSG) Boutros Ghali reviewed the agency's position regarding what peace-building constitutes. In 1995 the UNSG inaugurated the Supplement to an Agenda for Peace (henceforth UN agenda) to address the inadequacies of post-conflict peace-building. During the session, the UNSG advised that peace-building does not necessarily be undertaken at the declining stage of conflicts. They should also be initiated either as conflict prevention measures or concurrently deployed at different stages of a conflict (UNSG, 1995). Hitchcock (2004) maintains that the paradigm shift is consistent with broad interpretations of peace-building in the post 911, which addresses structural casualties, and initiates frameworks conducive to community relations that foster sustainable peace-building. The consolidation of peace through conflict lifeline demands more than political or diplomatic solutions. This stance is in line with that of the United Nations Secretary-General Ghali Boutros, who proposed the UN agenda, which informed the narrow understanding of peace-building, which views it as a diplomatic and humanitarian process. Alternatively, peace-building should be initiated at the earliest indication of tension or in a situation of potential conflict. It also champions the initiation of peace-building intervention initiatives at different stages of conflict lifeline (Neetling, 2016 and Tschirgi, 2003).

As a result of which the theory and practice of peace-building have been modified, duration has also lengthened, the scope expanded, engagement diversified, and new actors have also emerged (Gustavo et al., 2012; King et al., 2011; 2012). In practical terms, this reorientation also broadened the scope of peace-building to include any intervention military or civil targeted at preventing or resolving violent conflicts. Unlike conflict prevention, peacemaking, and peacekeeping, which emphasize enforcing peace using military firepower or presence, under the UN agenda, peace-building preoccupies itself with fostering an environment that reduces the probability of violent conflict, as opposed to dealing with principal actors in a conflict or issues as implied by other terms. To this end, peace-building is more of a means than an end (Damian, 2002).

Preceding the UN agenda is the discourse between negative peace and a positive one (Lund 2001). In concise terms, negative peace is said to prevail in the absence of violence, while positive peace is underscored by conscious efforts to promote harmonious existence based on human rights, social, economic and political justice (Murithi, 2016). To this end, positive peace is pursued when there is an understanding between actors in a conflict or those affected by strengthening their collective capacity to promote enduring relationships that may result in positive peace.

Furthermore, Willer (2014) argues that collective endeavors earn individuals improved status by signaling their concern for the group's welfare relative to their own, while fostering a sense of belongingness. Besides which individuals' inclination to participate in group activities leads to greater feelings of group solidarity, all of which are essential for building sustainable peace agreements. On this basis the paper argues in favour of community-centric peace-building initiatives as panaceas for fostering positive peace and consolidating the military campaigns against Boko Haram. An inclusive CCA that mobilizes cross-sector (civil and military) expertise and resources can prevent the outburst of violent conflicts and foster enduring relations amongst conflict actors and their host communities. According to UNICEF (2019), community involvement in peace-building transcends the boundaries of dialogue or formal peace agreements. Among others, it emphasizes the integration of affected communities in all 
aspects of decision-making, local ownership of policies and programs, which improves transparency, accountability and optimal resource allocations across diverse settings. Within the Community Centric Approach (CCA), peace-building obtains in the mobilisation and deployment of a range of community-oriented measures targeted at transforming conflicts to sustainable peace relations and outcomes (Lederach, 1995).

Concerning structural design and implementation, Haider (2009) opines CCA interventions are designed with the objectives of building partnership amongst a wide range of actors beyond the humanitarian and development community. This may include but not limited to diplomatic actors, conflicting parties and the host communities of these conflicts and actors. The CCA approach emphasizes the significance of addressing context-specific demands and needs of affected communities before other interests are considered. It is thought that the CCA approach has, in other times, had positive effects on the re-establishment of relations between the state and society through the provision of local service and infrastructure that have deteriorated or collapsed as a result of conflict or fragility. It is thought that community-managed peacebuilding interventions are efficient and cost-effective outcomes in the absence of red tape bureaucracy, and also lower's the operational cost on the principle of community contributions of labor and volunteerism and affords better knowledge of local terrains (World Bank, 2006; Slaymaker et al., 2005).

Besides, CCA could also be designed to suit various stages of conflict and fragility, as it can also be framed to counter the breakdown of social order and peace. Central to the success of this approach is the presence of the government and the numerous responsibilities that accompany it in conflict-ridden society, which includes the aversion of humanitarian crises, and fostering a sense of belongingness (Haider, 2009). Another crucial element is the degree of communal solidarity in conflict-ridden communities. Achieving social cohesion demands that members of the community (ex-combatants, resettled Internally Displaced Persons (IDPs), government institutions, security agencies and development partners) recognize each other as stakeholders harnessed with the mandate of promoting wellbeing of everyone affected by a conflict (Murithi, 2016). This component is integral considering that the impacts of violent conflict are often extensive and far-reaching. The pursuit of multiple aims concurrently through community-based approaches can be an efficient and effective way to contribute to peacebuilding. This view acknowledges the holistic nature of peace-building and how various elements are connected (Slaymaker et al., 2006; Haider, 2009).

In lieu of the protracted Boko Haram insurgency, it has become pertinent for the state to consolidate the relative gains of the military to circumvent degeneration of peace in communities once under the control of the insurgents by pursuing positive peace. Arguably, attaining a condition of positive peace in the presence of challenges above is increased when communities enjoy a degree of collective security such that the leeway of a return to Boko Haram's reign of terror is minimized. In other words, sustainable peace at the societal level depends significantly on the degree of collective freedom from want and fear, which can be brought about by deploying multi-sector resources and expertise. While the CCA remains a viable approach for re-establishing the link between the state and war-ravaged communities, the Nigerian state seems to be preoccupied with deploying the state-centric approach, relying on military capabilities to counter the influence of Boko Haram, with inconsequential attention been paid to peace-building, reconstruction and reintegration of displaced persons, as well as the deradicalization of defecting combatants. 
Further to which the international community and donor agencies stepped up its stabilization interventions in the region and beyond. For instance, the Lake Chad Basin Commission and the African Union Commission have adopted a regional stabilization strategy, which highlights immediate and long-term stabilization, resilience, and recovery needs of war-ravaged communities and civilian populations (African Union, 2018). The efforts by international donor agencies resulted in the implementation of a community referent (bottom-up) stabilization. These interventions include programs aimed at strengthening local conflict prevention and mitigation systems, restoring local governance and basic services, and fostering social cohesion and ensuring the reintegration of ex-combatants (Brechenmacher, 2019). Findings of a study by the UNODC report titled The Road to Extremism, which explores the drivers of radicalization shows the highly localized nature of recruitment, these findings highlight the plausible roles the community plays in curbing Boko Haram' recruitment (UNODC, 2020). In a related argument Crenshaw (1991) argues terrorism and insurgency are not committed by an individual, they are acts committed by a group of individuals who reach collective decisions based on shared belief systems, even though level of individual allegiance and participation varies, in the absence of collective actions aforementioned phenomenon are less likely to manifest.

Despite the promising outlook of the bottom-up stabilization interventions, Nigeria's overreached, under-funded, inconsistent, under-equipped and corruption-ridden security apparatus has struggled to consolidate the gains of joint military forces and civilian task force fighting Boko Haram. This reality in part constitutes a major challenge for displaced civilians who face threats from both insurgents and counterterrorism operations. Through the Presidential Committee on Northeast Initiative, the Nigerian government plans to tie reconstruction with community-based development, with the aim of fostering an inclusive approach to recovery, reintegration and stabilization in service delivery. Regrettably, pervasive government inactivity, particularly the lack of local political accountability and weak state incentives to prioritize service delivery, present significant hurdles that need to be addressed in long-term program planning and design. Efforts to stabilize affected communities and reintegrate internally displaced persons have proven counterproductive, besides individuals affiliated with violent extremist groups have multiplied, all of which is tied to the emphasis on militarized conflict response as the mainstay of framework for countering insurgency (Onapajo et al., 2020; Olusegun et al., 2019 and Brechenmacher, 2019).

Although the government rolled out its development and reconstruction program in 2016, there is reason to believe the intervention titled Presidential Committee on Northeast Initiative (PCNI) has failed to meet the growing humanitarian crisis. The plan which seeks to reconstruct the war-ravaged northeast, mobilize cross-sector expertise and resources to tackle the humanitarian crisis and jumpstart the region's economies, and strategically reposition the region for long-term prosperity, has fallen short of meeting the objectives for which it was drafted. The Buhari plan, also referred to in other times, has also failed to foster equal access to basic services and infrastructure; while promoting a civic culture that integrates zero tolerance to sexual and gender based violence. Further to which the government's seeming reliance on military force to stabilize Boko Haram's stronghold, out-shadows the much needed initiative (PCNI, 2017).

On this basis, the paper problematizes continued emphasis on conventional military tactics as the mainstay of counter insurgency operations against Boko Haram. In amongst other implications, the reliance on force suggests Nigeria has failed to take a cue from the 
counterproductive outcome of the United States reliance on military capabilities in the early years of its war on global terror. Alternatively, it is the opinion of the study that the implementation of a community-centric conflict degeneration and prevention mechanism will likely address the problems of local security threats with the aid of military presence and community policing. Yet to date, efforts to mobilize cross-sector expertise and resources to counter the influence of Boko Haram, resettle displaced persons and jump-start economic recovery have been relatively unsuccessful. As a result, pre-existing frameworks for countering the insurgency, have failed to satisfactorily tackle determinants of the conflict, drivers and structural problems that go beyond the capacity of local governments, including chronic corruption and weak accountability and oversight in the security sector. In the coming section, the study examines the limitations of pre-existing frameworks for countering the influence of Boko Haram to build its argument, which favors a reorientation of the military's role in the context of Nigeria's counter-insurgency operations.

\section{An Overview of Military Strategies for Stabilizing the Northeast}

Before moving on to examining the myriad of stabilizing efforts put in place by governments past and present, it is imperative to highlight the propensity of the Boko Haram conflict in the northeast region where the insurgents hold sway. Ten years of protracted insurgency and counter military operations have aggravated pre-existing disparities between inhabitants of the northeast comprising Borno, Yobe and Adamawa in relation to other parts of Nigeria. The region has incurred a conservative estimate of US\$8.9 billion in damages to its infrastructure, and unquantifiable negative effects on the capacity of the government (local and central) to deliver public goods and social services. The worst hit state, Borno, accounts for around 80 per cent of the internally displaced people, in addition to consequential damages to infrastructure and socioeconomic institutions to the tune of $\$ 6.9$ billion in the last decade. Further to which evidence abounds to suggest, housing, healthcare, agricultural, and education sectors were affected the most. Damages to housing infrastructure stands at ninety five per cent across states where Boko haram hold sway. Yobe for instance is estimated to have suffered $\$ 1.2$ billion in losses (13 percent of all infrastructure and social service damages in the region) while Adamawa State recorded an estimated \$ 829 million in losses, amounting to an estimated nine per cent of the total infrastructural damages in the north-east (OCHA, 2019).

Building on the vast literature, this section attempts to make sense of Nigeria's primarily reliance on force, which remains as a crucial component of counter insurgency operations. As frontiers of the global war on extremism, insurgency and terrorism, the United States government adopted the Army Field Manual (AFM) for counter-insurgency which defines the rules and parameter of engagement in unconventional wars, like that of Nigeria against Boko Haram. The manual emphasizes the centrality of deploying context-specific frameworks for counter-insurgency operations and that of Winning the Population (WTP) or Community Centric Approach as crucial to curbing the influence and spread of extremist ideals. Invariably, the WTP approach has become the American Army's new way of war. This reorientation moves beyond simple Army doctrine for countering insurgencies to become the defining characteristic of the Army's new way of war. In this sense, everyone is a counterinsurgent. The AFM acknowledges insurgencies unlike other battles and not fought and won exclusively on the battlefields; instead, the course of conflict will be decided by forces operating among the world's people. Here, the margin of victory will be measured in far different terms than the wars of our past. The idea of populations as the prize in war underscores the US Army's orientation for countering insurgency (Gentile, 2009). The logic behind a review of the US 
framework obtains from the need to invalidate legitimacy seeking efforts of insurgents, who in other times appeal to the population by highlighting unresolved issues and grievances within society to foster social acceptance and sympathy (Colombo, 2019).

Contrary to this approach is the kill-capture approach. In essence the approach emphasizes a reliance on military capabilities to decapitate insurgents through military highhandedness. In assent to this worldview, Nigeria's former President Goodluck Jonathan, referred to Boko Haram as an emerging frontier in the global war on terror, one which requires military campaigns. In the pursuit of this approach, the Nigerian government increased annual military spending from $\$ 625$ million in 2010 to over $\$ 1$ billion in 2012 (Salihu et al., 2021; Campbell, 2014). The kill-capture approach obtains in the use of force, violence, detention and neutralizing insurgent formations, disruption of supply network and decapitation of insurgent's organizational structures (US Government Guide for Countering Insurgency, 2009). It represents a kinetic approach to the unconventional tactics of guerrilla warfare and hit and run tactics employed by insurgents (Guide to the Analysis of Insurgencies, 2012).

The military approach could be targeted selectively at insurgents or indiscriminately at areas believed to be under the control of insurgents. In the former, the military targets individual affiliates of insurgent groups and those who support them in different capacities. Intuitively, the approach is known to have had suppressive effects on the influence and military capabilities of insurgents, and makes participation in insurgency costlier relative to indifference of sympathy for constituted authority (Kalyvas, 2006). In the context of indiscriminate military offensives, states are predisposed to punish civilians on the assumption of their affiliation with an insurgency, regardless of whether they actively participate in acts of violence or extremism. The approach is not only perceived as counterproductive, it negates loyalty to the state, and could be in other times costlier than neutrality, which means it forces civilians to either have sympathy for an insurgent group or to even join them (Kocher et al., 2012).

In addition, the indiscriminate approach seems to stem the tide in favor of the insurgents, in the sense that even when civilians do not join insurgent groups or profess their adoration for them, as a show of their resentment for state sponsored indiscriminate violence, they are likely to withhold Intel or insurgents activities or provide insurgents with intelligence. This in turn furthers the growth of the insurgency (Berman et al., 2013). Despite its evident shortcomings and probable counter productiveness, the seeming predisposition of states to deploy indiscriminate violence such as airstrikes, drone strikes and ground military presence remains puzzling (Kalyvas, 2006). In part, it is thought that lack of credible intelligence gathering strategy and sheer disregard for civilians caught in the crossfire (Lyall, 2009).

Regrettably, Nigeria's handling of Boko Haram from inception, arguably informed Boko Haram from a group of disgruntled groups with extremist religious tendencies to an all-round insurgent sect. Evidence from prior studies show Boko Haram has been in existence long before its confrontation with security operatives in 2009. The indiscriminate killing of its unarmed devotees and that of its s relatively non-violent leader Muhammad Yusuf, in police custody in 2009 arguably informed the militarization of Boko Haram. Ever since, the insurgents are driven by their pursuit for vengeance against political elites, opposing Islamic scholars, security operatives and the Nigerian state as a result of its brutal suppression sometime in 2009 . Nonetheless, Boko Haram has proven to be adaptable, evolving its tactics and changing its targets upon Abubakar Shekau's ascension to the mantle of its leadership sometime in 2010. The pace at which the insurgents grew its military capabilities both in guerrilla warfare and 
production of improvised explosive devices and enlist suicide bombers to deliver them suggests their alliance with global terror organization (Eweka et al, 2016). Unlike Al-Qaeda, Al-Shabab and the Taliban, the operations of Boko Haram remains largely confined to Nigeria and neighboring Chad, Cameroon and Niger, with little evidence to suggest the group intends to take its war on constituted secular authorities and values to Western powers that remain the global frontiers in the war on terror, insurgency and religious extremists (Walker, 2012).

The decision to deploy indiscriminate military force against Boko Haram has failed to diminish the capacity of the insurgency; rather its counter productiveness has alienated the region's civilian population, fostering widespread dissatisfaction amongst the affected population. Prevailing disconnects between counterinsurgency approach and affected communities were exacerbated by the imposition of a state of emergency in Boko Haram strongholds of Borno, Yobe, and Adamawa states respectively. In damning statements and high-profile meetings, suggestions of world powers (U.S. and EU member states) to the Nigerian state to commit more resources that will afford protection for civilians caught in the crossfire, seemingly fell on deaf ears. Not only has the violence increased, counterinsurgency strategies pay minimal attention to tackling the principal drivers of the insurgency (Vanguard, 2012). In astute disregard of these warnings, former President Jonathan between 2012 and 2015 requested for more fiscal and military assistance from the international community, as his administration went on to downtune the propensity of dysfunction and seeming incompetence within the Nigerian military and the worsening humanitarian crisis. As a result, the bilateral relationship between the United States and Nigeria was dealt a blow, although bilateral ties have since been re-established (Pechenkina et al., 2017; US Department of State, 2017). Under President Jonathan 2010-15, Boko Haram increased its military capacity and attained global recognition after it abducted hundreds of school girls from Chibok, many of who remain in captivity till date.

In part, President Jonathan lost his bid for a second term in office due to his administration's poor handling of Boko Haram's threat to Nigeria's unity (Ibiang, 2018). On assuming office in 2015, the President Buhari led government made considerable gains against Boko Haram. Not only did the joint military operations amount to the recapture of communities once under Boko Haram control, security forces were able to smoke the insurgents out of hiding into the vast Lake Chad region. The military campaign against Boko Haram pushed them to rural areas and border communities; regrettably, it has been accompanied by a handful of ripple effects and unintended negative consequences. For instance, there has been a surge in the number of internally displaced persons, since military aggression was heightened against the sect (UNHCR, 2019). Relatedly, Boko Haram has disrupted the flow of essential staple foods like beans, pepper and tomatoes which are cultivated in the Northeast region, resulting in the increase of food prices. Forced displacement creates a range of ripple effects, like physical and psychological trauma and social and economic hardship, it also creates a conducive atmosphere for radicalization and in other times conscription of desperate and fleeing youths (Eme et al, 2014). Furthermore, displacement worsens the already existing situations of poverty and deprivation and its effects are felt not only by the displaced themselves, but in the host communities in which they take refuge. Evidence suggests, $92 \%$ of those displaced by the armed conflict have been taken in by host communities who share space, resources, and services with them, which are generally already overstretched and increasingly under severe strain (Presidential Committee on Northeast Initiative, 2016).

Against the backdrop of claims suggesting factionalization and splinter cells within Boko Haram's structure (Onapajo et al, 2020), and emerging threats of banditry, lingering farmers- 
herders conflict, there is cause to suggest, the Nigerian government has not made consequential gains against Boko Haram, be it on the battle field or in the area of safeguarding those trapped in conflict areas, and in alleviating the plight of those who have either lost means of livelihood or displaced as a direct consequences of the insurgency or counterinsurgency operations. Ideally, it is not expected that Boko Haram will be mindful of spilling civilian blood, given their indiscriminate crusade of terror against civilians, notable however is the role of government in carrying out its statutory responsibility of safeguarding its territory, the subjects which live within such a territory and by extension their properties.

In 2016 Nigeria's framework for countering the influence of Boko Haram to accommodate a prison based deradicalization program (Operation Safe Corridor) for repentant and defecting Boko Haram combatants. Despite which the military plays a crucial role in the administration of the program. Not only have Nigeria's prison program been castigated for its exclusionary nature (Bukarti, 2019: Brechenmacher, 2018), the program lacks a coherent framework for reintegrating deradicalized combatants and other affiliates of Boko Haram. Nonetheless, Nigeria's counter insurgency frameworks remains highly militarized, given its seeming reliance on the kill-capture approach remains Nigeria's preferred strategy for countering Boko Haram. According to Jibrin et al, (2018) the rules of engagement in respect to the kill-capture approach are designed for conventional inter-state wars, rendering it counterproductive and problematic in the context of counterinsurgency. In what follows, the viability of broadening counter insurgency approach to accommodate a community referent peace-building intervention.

\section{Civil-Military Relations, a Model for Analysis}

Samuel Huntington's seminal study, The Soldier and the State 1957 was the foundation upon which contemporary theorists like Janowitz's Professional Soldier 1960 built their arguments on the relationship between the civilian state and its military forces. As a concept, CMR is used to describe an array of circumstances and a complex set of issues ranging from command and control (civilian/political control of the military instrument) to all forms of interaction between the military and broader society. For this analysis, however, it is understood to mean the interaction between the military and communities within which active military interventions are undertaken (Damian, 2002). These interactions may include but are not limited to; intelligence sharing, humanitarian aid, reconstruction, security, amongst other forms of relations of interdependence and mutual assistance in times of war or peace. CMR is a multifaceted model that comprises a multitude of aspects associated with the interfaces between civilian and military actors. In the academic literature, CMR refers to theoretical approaches that examines the nature of interactions between political elites, military and citizenry by focusing on four specific elements of, the degree of civilian control over the military, the degree of the professionalism of the military, the interaction between civilian and military actors in times of peace and war; and the compatibility or divergence of their views (Andrews, 2008).

Regardless of the approach, civil-military relations have existed under different forms in multiple fields at national and international levels. Civilian and military actors have operated in the same environment for a long time ago (Hugo, 1996 and Sorenson, 2006), as such the relationship between them is not a new phenomenon. However, the changes in the international system in the post-Cold War era, the emergence of non-state actors and non-conventional threats, as well as the complex alterations in the area and means of warfare, gave rise to new 
trends and challenges for the interactions between these two actors. Besides the traditional context of an on-going war, it is possible to identify numerous other areas of interaction between civil and military actors. The complexity of such situations has led both civilian and military actors to understand the crucial significance of their cooperation (Antonio, 2016; Parepa, 2015). For this analysis, CMR is examined in the context of indigenous counterinsurgency framework which combines both military and non-military efforts to counter the influence of Boko Haram, while limiting the effects of humanitarian crises in worst hit regions.

The frequent use of concepts such as humanitarian aid assistance, peace-building and human security in a complex and fragile environment have become increasingly ascribed to emerging intra-state conflicts in the era of global interdependence. They bring to the fore the notion of human security from the perspective of freedom from want and freedom from fear. Against which, a relationship between development (freedom from want) and security (freedom from fear) has been acknowledged by the international community as core components of conflict resolution. The challenges faced in conflict and post-conflict situations to only one dimension either security or development would lead to negative peace outcomes. Highlighting the intricate and interdependent relationship between both concepts, the significance of development as a means of fostering security and the relevance of security as a means of fostering development is further established. On this note, it is thought that "war retards development, but conversely, development retards war (Collier, 2007). Relatedly, it has also been observed that in fragile states the interdependence between security and development is inescapable (Olson et al., 2007).

The territorial dynamics of intra-state wars, coupled with the involvement of multiple actors, of which affected communities constitute the most important actors, have heightened the complexity of conflict management and resolution. Hence, intervention frameworks require the implementation of a broad spectrum of tasks by the military. Nonetheless, conflict resolution is also done based on non-coercive measures, which implies that the use of the military should be balanced and integrated with other instruments of power. The traditional use of military forces in the context of conflict resolution seems to be undergoing rapid evolution, where its action is developed in a much more complex environment (Antonio, 2016). The security of civilians in fragile environments is a mutual objective for both military and humanitarian actors. Although the military have a clear comparative advantage, and : while the physical presence of aid agencies can in some circumstances be a deterrent to potential perpetrators of violence, unarmed aid workers are not equipped to robustly protect civilians from large-scale attacks (Svoboda, 2014). While both actors pursue the same goal, there have been instances where a lack of cordial relationship affects the probability of meeting their objectives of securing civilians. Invariably, the very civilians who they intend to protect are known to suffer the brunt of the conflicting relations between key conflict actors.

A review of pre-existing frameworks for countering the influence of Boko Haram shows the relations between military and civilian actors is anything but cordial. Some have cause to believe the sustained military offensive which seemingly takes the front burner of Nigeria's counter insurgency framework, is not only counterproductive, it terrorizes a population that was already weary of the state and its security forces, leading them in other times to sympathize with the insurgents, withhold vital information from government and even join the insurgents in extreme cases (Harcourt, 2018). At some point, the relations between military and humanitarian aid agencies in the Northeast, were involved in a frenzy of accusations and 
counter accusations, leading security forces to stifle humanitarian efforts and relief materials for regions worst hit by Boko Haram. The military hierarchy has since denied such allegations and responded by accusing humanitarian aid agencies of aiding Boko Haram (Human Rights Watch, 2020). Despite the evident failure of military highhandedness to counterinsurgency, seeming emphasis on military onslaught suggests that Nigerian government have not only failed to learn from the outcomes of counterinsurgency exploits of the American's and allied forces in Iraq and Afghanistan, but also continues to downplay imploding humanitarian crisis as a result of the insurgency and counter operations against it (Harcourt, 2018).

Although a strengthened, equipped and motivated military force remains crucial to winning the war on insurgency, however, prevailing disconnect between security (military) and development (civilian) actors suggests Nigeria could win the war against Boko Haram and still lose the war on insurgency. The relegation of the needs of affected civilian populations and worst hit communities has the potency to foster a sense of exclusion, which ideally favors the insurgents. Further to which, aggrieved persons may also be left with little to no choice but to become devotees or members of the insurgent group, if it guarantees them a means of livelihood.

In an interview with a defecting female Boko Haram devotee named 'Amina,' who is currently seeking refuge in one of numerous camps for internally displaced persons, Amina asserts the prevailing limitation she and other refugees are faced with. In amongst other challenges, she claims there was limited opportunity to work and earn a living, against which they are compelled to engage in sexual intercourse with camp officials who exploit their vulnerabilities in exchange for food and essential supplies. Further to which she claims "most Boko Haram female devotees now regret their decision to defect, because life is just so hard. Another respondent's names withheld buttresses Amina's claims of neglect by state authorities and the sexual exploitation they endure in the hands of officials on a regular basis (Azadeh, 2019). In the absence of favorable living conditions, and requisite infrastructure in affected communities, the likes of Amina will likely take up offers to rejoin Boko Haram should the opportunity avail itself. Against this backdrop, the implementation of a people-centric counterinsurgency which takes into account the reconstruction and reintegration of displaced persons, the relative gains of the military are unlikely to have any sustainable impacts.

\section{The Military, Counter Insurgency and Peace-building in the Northeast}

In How Everything Became War and the Military Became Everything, Rosa Brooks elucidates how since the events of 9/11 conventional military roles have been broadened, in addition to increasing encroachment of the military on civil matters. Brooks foresees a world where the distinction between war and non-war, military and nonmilitary have eroded conventional military's orientation built around the use of coercion. It is a world in which, Brooks opines, contrary to conventional knowledge, the military is no longer equated with guns and battlefields, they are now made to undertake roles previously assigned civilian like "train Afghan judges and parliamentarians, develop television soap operas for Iraqi audiences, and conduct antipiracy patrols off the Somali coast as part of wider measures to foster sustainable peace in fragile societies. They also carry out surveillance of communications, infiltrate terror organizations, and pilot weaponized drones from simulated airplane cockpits thousands of miles away (Brooks, 2016: p. 341). 
Regrettably, the kill or capture approach, rising military budget, suggests a subordination of the concerns for growing civilian displacements amongst other resulting humanitarian crises resulting from a decade of Boko Haram's reign of terror (Army Technology, 2021). Further to which the paper contends, the protracted nature of the insurgency demands a review of preexisting COIN frameworks to suit existential realities at different stages of the conflict. As such, it will be illogical to put on hold reconstruction of the war-torn region and reintegration of millions displaced by the conflict and recivilization of ex-combatant until the insurgency deescalates.

The rationale behind the existence of modern nation-states derives from amongst others statutory obligations, the protection of lives and property of citizens. If prevention is not possible, the so-called "peacekeepers", ideally the military, are deployed to help enforce and maintain a safe environment, preventing the resumption of violence and providing a safe space for the advancement of communal dwelling (Ramos-Horta, 2015). The traditional use of military forces in the context of conflict resolution seems to be undergoing rapid evolution, where its action is developed in a much more complex environment (Antonio, 2016; Smith, 2008). Hence, military operations in complex terrains like that of northeast Nigeria require a framework that supports Civil-Military Relations (CMR). Regrettably, this is far from the reality, the relations between the military which is charged with the responsibility of fostering security and civilian actors who sought to alleviate the humanitarian blow-backs of conflicts and foster reconstruction amongst other roles, is everything but cordial. The unconventional guerrilla and terrorist approach employed by the insurgents make it difficult to emphatically arrive at a conclusion as to whether Nigeria is winning or losing the war against Boko Haram. Instead, there is cause to believe pre-existing state-referent framework for countering Boko Haram has negative effects on building community resilience.

Elsewhere, it is argued that counter insurgency operations against Boko Haram have exuberated threats of insecurity and fear amongst the civilian population in affected communities. Unending gun battles between the military and Boko Haram has forced civilians to abandon their homes and means of livelihood, resulting in a grave humanitarian disaster (Ewa, 2018). The militaristic approach has also alienated development partners and humanitarian agencies who are considered crucial actors in the design and implementation of a community centric peace-building.

In one of such instances, following a war of words between security forces and humanitarian agencies in 2019, the military redeployed officers as a way of taking their pound of flesh, after a disagreement with several humanitarian agencies and development partners. The move by the military according to Human Rights Watch (2019) left an estimated 223, 000 civilians without security and another 100,000 has been cut off from humanitarian and aid supplies. Findings from a United Nations Office for the Coordination of Humanitarian Affairs (2019) study suggests in the same period aid agencies could not reach 823, 000 people as a result of the deployment. As a result of military highhandedness and their alienated counterinsurgency approach, President Obama and congressional leadership blocked plans by Israeli government to sell Supra Tucano warplanes to Nigeria, which required congressional approval (Cooper et al, 2016). The sale was put on hold after a fighter jet owned by the Nigerian Air force bombed a camp for IDPs, killing an estimated 230 people (Nigeria Counterterrorism and Extremism Report, 2020). The US Army in acknowledging their deficiencies in countering extremism in faraway Middle-East, claim military operations that successfully counter insurgencies are 
usually those able to overcome their institutional inclination to wage conventional war against insurgents. They learn how to practice COIN and apply that knowledge (US Army, 2006).

The lack of cooperation between security and development is evident in the relations between military and civilian actors in the on-going efforts to counter the influence of Boko Haram, and ameliorate the resulting humanitarian crisis. Feaver (1999) demystifies the complexes of CMR on the basis that the military must at all cost possess the capacity to prevail in conditions of war and its obligation of protecting the state against internal or external aggression. One purpose behind establishing the military in the first place is the need, or perceived need, for military force, either to attack other groups or to ward off attacks by others. On the other hand, just as the military must protect the polity from enemies, so must it conduct its own affairs, so as not to destroy or prey on the society it is constituted to safeguard, because the military must face enemies, it must have coercive power, the ability to force its will on others. But coercive power often gives it the capability to enforce its will on the community that created it.

The fragile environment within which both actors operate arguably complicates the nature of their relations, in the absence of formally established joint roles both actors are predisposed to act arbitrarily. This however is not unexpected given their divergence in objectives, nonetheless the paper argues in favor of a reorientation of the role of Nigeria's military as wider efforts to counter the influence of Boko Haram. Proposed reorientation should take into context, sustained military presence in fragile communities, provision of security for aid convoys, fostering cordial relations in communities where counter operations are conducted. At the same time, drafting civilian actors alongside the military could compromise intelligence or jeopardize the discretion by which the military operates. For Ramos-Horta (2015), to address the complexes of CMR, the different threats should be countered with the commensurate use of force no more no less. The proportionality in threat-forces should inform the response which could range from deterrence to containment, through intimidation and coercion to direct confrontation. Military force should be used accurately, proportionately and appropriately within the principle of minimum force necessary to achieve the desired effect, while at the same sustaining consent for the mission and its mandate. Put differently, the military does not have to use force when it is not entirely necessary.

\section{The Military, Counter-Insurgency and Peace-building, Prospects and Challenges}

While in no way is peace-building a core competency of either the military or humanitarian agencies, over time it has become a peripheral concern for both actors. Peacebuilding is explicitly recognized in some military doctrine and aid agency policy, although each actor interprets the concept different ways. Generally speaking, military forces provide a secure environment for peacebuilding to occur whereas humanitarian agencies help build stable relations amongst war affected communities. A peacebuilding perspective of civil-military relations assumes that military and humanitarian actors each form one strand of activity towards achieving wider goals of fostering peace and stability. Where these actors operate in close proximity and where the actions of each will impact on the other, enhanced management of the relationship between them may in some cases contribute to peace-building (Damian, 2002). Regrettably, existential realities in the northeast suggest a near absence of cordial relations between the military and civilian actors that could set the tone for mutual assistance. 
One of the key factors affecting the reorientation of the military remains the seemingly weak civil control over the Nigerian military. Constituted authority as enshrined in the 1999 constitution as amended, subordinates the military to civil control and parliamentary oversight. But, the problem lies with implementation. The culture of civilian supremacy over the military is yet to attain a significant level of institutionalization in the developing world. The result is that citizens counteract abuse by the military in various ways. One way is to simply comply with the demands and orders of the soldiers, even when they are illegitimate. Another entails non-violent resistance or non-compliance. For example, it's common for civilians to refuse to cooperate and share information with the military (Sallek, 2019).

Furthermore, it is imperative to orient the military on the parameters of engagement in fragile environments such as those where counter operations against Boko Haram are underway. To increase the probability of success, the military needs to move from a reactive approach to the effective use of force to a proactive one, in order to reduce the risks of carrying out a mandate and minimise casualties (Mood, 2015: 4). This implies that the effective response capability to threats must be obtained and maintained throughout the operation, and that the forces hold the initiative needed to adapt and react faster than any threats, taking necessary measures to maintain consistency in performance and ensure greater operational flexibility (Marten, 2004:152). But to be proactive and stop the initiative, military force must have the necessary means. Well-equipped and trained troops will be an important element to deter potential offenders and reduce the level of violence, as weak and passive military components invite aggression and manipulation, leading to increased risks of unnecessary losses of life (Mood, 2015: 4).

\section{The Way Forward}

The review of relevant theoretical and conceptual literature reveals a handful of issues not to be extensively addressed for the aims and objectives of a community centric peace-building to be brought into fruition. However, the following specific recommendations are proffered as solution: thorough reconciliatory and re-settling of the all belligerents, practical rule of law, job opportunity and poverty alleviation program, stringent anti-corrupt practices, proper reintegration of citizens and security sectors, civil education, transparency and general accountability, human security and infrastructural facilities, nationalistic leaders, and good governance, gender sensitivity are some the requisite for building positive peace in affected communities.

On the subject matter of the role of the military in peace-building, it is imperative that when undertaking operations in fluid operational environment like Nigeria's northeast, to minimise casualties and reduce the risks related to the implementation of the mandate, it is essential that the military component of the operation can adopt a proactive approach to the effective use of force. This component must therefore guarantee external and internal conditions, enabling the effective employment of combat capabilities in order to be qualified as a genuinely useful instrument in this context. Externally, these conditions have been based on Chapter VII of the UN Charter, guaranteeing the formal legitimacy and the will of the State contributors of military forces in deploying the appropriate means, framework and command arrangements that permit its effective operational use. But for the military component to be proactive and stop the initiative, it must also ensure a set of internal conditions, such internal organizational coherence with civilian actors, availability and interoperability of the necessary means and equipment, as well as having appropriate training. These conditions allow throughout the 
operation the ability to adapt and react faster, enabling the force to respond effectively to threats and keep the initiative necessary for consistency in performance as well as to ensure operational flexibility

\section{REFERENCE}

African Union (2018). Ministerial Conference on the Adoption of the Regional Stabilization Strategy for the Lake Chad Basin Region," African Union's Peace and Security Department, August 31, 2018,

Agbiboa, D.E. and Maiangwa, B. (2013). Nigeria: Towards a Non-Killing Approach Boko Haram, Religious Violence, and the Crisis of National Identity in Nigeria: Towards a Non-Killing Approach. Journal of Developing Societies. 29: 379.

Ahmed, I. and Eckel, M. (2014). In The Home of Peace, A Siege of Fear. Boko Haram: A VOA Special Report. July, 21. URL:

https://www.voanews.com/MediaAssets2/projects/boko-haram/index_en.html

Allied Joint Doctrine (2010). AJP-01. OTAN-Bruxelas. Dezembro de 2010.

Andrew Walker (n.d.). What is Boko Haram? United States Institute for Peace, Special Report 308. URL: https://www.usip.org/sites/default/files/resources/SR308.pdf

Andrews, B.M. (2008). Patterns of Civil-Military Relations in Democracy. Fort Leavenworth Kansas: United States Army Command and General Staff College, School of Advanced Military Studies, 2008.

Antonio, O. (2016). The Use of Military Force in Management and Conflict Resolution. JANUS.NET, e-journal of International Relations. 7(1): 33-54

Army Technology (2021). Report: Nigeria's Defense Spending to Cross \$2dn Mark by 2022. Army Technology report.

Azadeh, M. (2019). What would make a woman want to go back to Boko Haram? Despair. The Guardian, January 14. Accessed from https://www.theguardian.com/commentisfree/2019/jan/14/woman-boko-haram-nigeriamilitant-group

Berman, E., Felter, J.H., Shapiro, J.N. and Troland, E. (2013). Modest, Secure, and Informed: Successful Development in Conflict Zones. American Economic Review: Papers \& Proceedings, 103(3), 512-517. DOI :10.1257/aer.103.3.512

Bernard E.H. (2018). How our Government Went to War Against its People, New York: Basic Books.

Brooks, R. (2016). How Everything Became War and the Military Became Everything: Tales from the Pentagon. New York: Simon \& Schuster, pg. 344, 341, and 14.

Campbell, J. (2014). U.S Policy to Counter Nigeria's Boko Haram, Centre for Preventive Action, Council on Foreign Relations, Council Special Report, November, 17. Available at; https://www.cfr.org/sites/default/files/pdf/2014/11/Nigeria_CSR70.pdf

Christopher Paul (2012). Winning Every Battle but Losing the War Against Terrorist and Insurgents. (eds) Brian Michael Jenkins and John Pau, The Long Shadow of 9/11. RAND Corporation

Collier, Paul et.al. (2007) Breaking the Conflict Trap: Civil Wars and Development Policy, Washington D.C.: The World Bank, p.1.

Condra, L.N. and Shapiro, J.N. (2012). Who Takes the Blame? The Strategic Effects of Collateral Damage. American Journal of Political Science, 56(1), 167187. [doi:10.1111/j.1540-5907.2011.00542.x] 
Cooper, C and Dionne, S. (2016). After Years of Distrust, U. S. Military Reconciles with Nigeria to Fight Boko Haram. The New York Times, May 15. Accessed from https://www.nytimes.com/2016/05/16/world/africa/boko-haram-nigeria-us-arms-saleswarplanes.html

Crenshaw, M. (1992). Current Research on Terrorism: The Academic Perspective. Studies in Conflict and Terrorism, 15, 1-11.

Eme, O., Onyishi, A., Uche, O. and Uche, I. (2014). Food Insecurity in Nigeria: A Thematic Exposition. Arabian Journal of Business and Management Review, 16(2): 232-243.

Ewe, O. and Olusegun, T.O. (2018). Management of Internally Displaced Persons in Africa: Comparing Nigeria and Cameroon, African Research Review, 10(40): 193-210.

Feaver, D.P. (1999). Civil military Relations. Annual Review of Political Science, 1.21, pp. 11-41.

Gustavo, D. and Ettang, D. (2011). Contextualizing the Peacekeeping and Peacebuilding Nexus. Conflict Trends, Issue. 3.

Huma Haider (2009). Community-based Approaches to Peacebuilding in Conflict-affected and Fragile Contexts. Issues Paper. Governance and Social Development Resource Centre (GSDRC). International Development Department, University of Birmingham.

Human Rights Watch (2012). Spiraling Violence: Boko Haram Attacks and Security Force Abuses in Nigeria. HRW Online, October 11. URL:

https://www.hrw.org/report/2012/10/11/spiraling-violence/boko-haram-attacks-andsecurity-force-abuses-nigeria

Human Rights Watch. (2020). Nigeria: Army Restrictions Stifling Aid Efforts: Threaten Staff Safety, Effectiveness in Region Hit by Boko Haram. HRW Online, March, 4. URL: https://www.hrw.org/news/2020/03/04/nigeria-army-restrictions-stifling-aid-efforts

Ibiang, O.E. (2018). Nigeria's Insurgency and Counterinsurgency: Implications, Issues, and Lessons for National Security, Review of History and Political Science, 6(1): 33-42

Jibrin, I. and Saleh, B. (2018). Civilian-Led Governance and Security in Nigeria After Boko Haram, Us Institute of Peace, Special Report. URL:

http://www.jstor.com/stable/resrep20243

Kalyvas, S.N. (2006). The Logic of Violence in Civil War. Cambridge University Press. 10.1017/CBO9780511818462

Kalyvas, S.N. and Balcells, L. (2010). International System and Technologies of Rebellion: How the End of the Cold War Shaped Internal Conflict.' American Political Science Review, 104 (3), 425-429. 10.1017/S0003055410000286

Kocher, M.A., Pepinsky, T.B. and Kalyvas, S.N. (2011). Aerial Bombing and Counterinsurgency in the Vietnam War. American Journal of Political Science, 55(2), 201-218. [doi:10.1111/j.1540-5907.2010.00498.x]

Long-Sutehall, T., Sque, M. and Addington-Hall, J. (2010). Secondary Analysis of Qualitative Data: A Valuable Method for Exploring Sensitive Issues with an Elusive Population. Journal of Research in Nursing, 16(4): 335-344

Lund, M. (2001). A Toolbox for Responding to Conflict and Building Peace, in Reychler, L. \& Paffenholz, T. (eds), Peacebuilding: A Field Guide. Boulder, Colorado: Lynne Rienner.

McIlreavy, P. and Julien, S. (2017). A collective shame: the response to the humanitarian crisis in North-Eastern Nigeria. Humanitarian Exchange: Special feature The Lake Chad Basin: an overlooked crisis, 70(11). Accessed from https://odihpn.org/wpcontent/uploads/2017/10/he-70-web.pdf 
Mood, R. (2015). Force Commanders' Advice to the High-Level Independent Panel on UN Peace Operations. Washington: ONU.

Nigeria Counterterrorism and Extremism Report (2020). Counter Extremism Project. Accessed from https://www.counterextremism.com/sites/default/files/country_pdf/NG$\underline{12172020 . p d f}$

Oliveira, A. (2016). The use of military force in the management and resolution of conflicts. Janus.Net e-journal of International Relations, 7(1). Accessed from observare.ual.pt/janus.net/en_vol7_n1_art3 (http://hdl.handle.net/11144/2621)

Olson, L. and Gregorian, H. (2007). Beyond Information Sharing \& False Coherence: Interagency Coordination in International Peace Missions, Policy Brief, Calgary: Center for Military and Strategic Studies, p.1.

Onapajo, H. and Ozden, K. (2020). Non-military approach against terroriwsm in Nigeria: Deradicalization strategies and challenges in countering Boko-haram. Security Journal, 12. Available at; https://doi.org/10.1057/s41284-020-00238-2

Parepa, L. (2015). Challenges of Civil Military Relations in Peace Support Operations: Examining the Framework of Comprehensive Approaches, UN. Peace and Progress, 2(1): 23-45.

Paul Christopher, Colin P Clarke and Beth Grill. (2017). Victory Has a Thousand Fathers. Sources of Success in Insurgency. RAND Corporation.

Pechenkina, A.O. and Bennett, D.S. (2017). Violent and Non-Violent Strategies of Counterinsurgency. Journal of Artificial Societies and Social Simulation 20 (4): 11 DOI:10.18564/jasss.3540

Ramos-Horta (2015). Uniting our strengths for peace - Politics, Partnership and People. Report of the High-Level Independent panel on United Nations Peace Operations.

Rialize Fereirra. (2017). Military Involvement in Post Conflict Transformation in African Peace Building. Journal of Military Studies, 45(1): 1-20

Rob Willer (2014). A Status Theory of Collective Action.

Salihu, M. and Yahaya, Y. (2021). Beyond the Battlefields, Non-Militarized Approach and Management of Armed Conflict in Nigeria: Takeaways from Operation Safe Corridor. African Journal of Peace \& Conflict Studies, 10(1): 123-145. DOI: https://doi.org/10.31920/2634-3665/2021/v10n1a6

Sallek, Y.M. (2019). How using the Military is Causing and Not Solving the Problem. The Conversation, May 14. Accessed from https://theconversation.com/how-using-themilitary-in-nigeria-is-causing-not-solving-problems-116676

Slaymaker, T., Christiansen, K. and Hemming, I. (2005). 'Community-Based Approaches and Service Delivery: Issues and Options in Difficult Environments and Partnerships'. Overseas Development Institute, London

Slim, H. (1996). The Stretcher and the Drum: Civil Military Relations in Peace Support Operations. International Peacekeeping, 3(2): 123-140;

Smith, Rupert (2008). A Utilidade da Força, A Arte da Guerra no Mundo Moderno. Lisboa: Edições 70

Sorensen, B.R. (2006). Violence and humanitarian assistance: Reflections on an intricate relationship. Journal of Humanitarian Assistance, 14-19.

Stengel, R. (2017). Why Saying 'Radical Islamic Terrorism' Isn't Enough. New York Times, February 13, accessed from https://www.nytimes.com/2017/02/13/opinion/why-sayingradical-islamicterrorism-isnt-enough.html 
Tim Murithi. (2016). African Approaches to Peacebuilding and Social Solidarity. Accord AJCR 2016/2. URL: https://www.accord.org.za/ajcr-issues/african-approaches-tobuilding-peace-and-social-solidarity/

U.S Department of State (2009). US Government counterinsurgency guide. Bureau of Political-Military Affairs, U.S. Department of State. Guide to the Analysis of Insurgency. (2012). Vol. Accessed online on February 7, 2015 Published by the US Government. Washington DC: CIA Publication.

U.S. Department of State (2017). Boko Haram and U.S. Counterterrorism Assistance to Nigeria in Beth Ellen Cole, et al. (2017) Breaking Boko Haram and Ramping Up Recovery: US Engagement in the Lake Chad Region, United States Institute of Peace, $225-7$

UNICEF (2019). Minimum Quality Standards and Indicators on Community engagement, 2019.

United Nations Office for the Coordination of Humanitarian Affairs, (2019). About OHCA Nigeria. URL: https://www.unocha.org/nigeria/about-ocha-nigeria

United Nations. (2020). Situation in West Africa, Sahel 'Extremely Volatile' as Terrorists Exploit Ethnic Animosities, Special Representative Warns Security Council. SC Press Release, July 4. URL: https://www.un.org/press/en/2020/sc14245.doc.htm

United Nations. (2020). Situation in West Africa, Sahel 'Extremely Volatile' as Terrorists Exploit Ethnic Animosities, Special Representative Warns Security Council. SC Press Release, July 4. URL: https://www.un.org/press/en/2020/sc14245.doc.htm

US Department of the Army. (2006). Counterinsurgency Field Manual. Interim, No. 3-24, Washington: Author.

Vanguard (2012). Jonathan Seeks Foreign Assistance to Tackle Boko Haram. Vanguard, April 20, 2012, accessed from https://www.vanguardngr.com/2012/04/jonathan-seeksforeign-assistance-to-tackle-boko-haram/

World Bank (2006). Community-Driven Development in the Context of Conflict-Affected Countries: Challenges and Opportunities. Social Development Department, Environmentally and Socially Sustainable Development Network, World Bank, Washington, DC 